\title{
Two Years of Oceanographic and Meteorological Data from the UNAM Buoy Anchored at Socorro Island in the Mexican Pacific
}

\author{
D. A. Salas-de-León1 ${ }^{*}$, M. A. Monreal-Gómez¹ , A. Gracia1 ${ }^{\text {, D. Salas-Monreal2 }}$ \\ ${ }^{1}$ Instituto de Ciencias del Mar y Limnología, Universidad Nacional Autónoma de México, Mexico City, México \\ ${ }^{2}$ Instituto de Ciencias Marinas y Pesquerías, Universidad Veracruzana, Veracruz, México \\ Email: dsalas@unam.mx
}

Received 16 January 2015; accepted 25 March 2015; published 30 March 2015

Copyright (C) 2015 by authors and Scientific Research Publishing Inc.

This work is licensed under the Creative Commons Attribution International License (CC BY).

http://creativecommons.org/licenses/by/4.0/

\begin{abstract}
The paper analyzes oceanographic and meteorological data registered by an oceanographic buoy in the Mexican Pacific. In 2005 the Marine Science and Limnology Institute of the National Autonomous University of Mexico moored an oceanographic buoy off the coast of Socorro Island in the Mexican Pacific that transmitted data hourly from July 11, 2005 to November 15, 2007. The buoy recorded oceanographic (current speed and direction, conductivity, temperature, salinity, density, turbidity, pH, fluorescence, sea level, waves, and tides) and meteorological (wind speed and direction, temperature, relative humidity, and pressure) data. Linear spectral analysis and wavelet analysis revealed annual, seasonal, and biweekly frequencies, as well as frequencies associated with the main tidal components, and those corresponding with inertial oscillations and MaddenJulian oscillations.
\end{abstract}

\section{Keywords}

Socorro Island, Mexican Pacific, Currents, Tides, Sea Level, Madden-Julian

\section{Introduction}

In light of increasing concerns about climate change, global warming, the decline of fisheries of commercial importance, extreme drought or rainfall, and increased navigation with business objectives, it is clear that a bet-

\footnotetext{
${ }^{*}$ Corresponding author.

How to cite this paper: Salas-de-León, D.A., Monreal-Gómez, M.A., Gracia, A. and Salas-Monreal, D. (2015) Two Years of Oceanographic and Meteorological Data from the UNAM Buoy Anchored at Socorro Island in the Mexican Pacific. Open Journal of Marine Science, 5, 182-192. http://dx.doi.org/10.4236/ojms.2015.52015
} 
ter understanding of the oceanographic and meteorological processes is needed. To address this issue, in 2005 the Marine Science and Limnology Institute (ICML) of the National Autonomous University of Mexico (UNAM) deployed an oceanographic buoy near Socorro Island as part of the Telemetry Oceanographic Monitoring of the Mexican Pacific Ocean Project. Socorro Island is part of the Revillagigedo Archipelago in the Mexican Pacific Ocean (Figure 1). The Revillagigedo Islands constitute one of three Mexican island groups in the Pacific Ocean that are not on the continental shelf; the other two are Guadalupe and Rocas Alijos Islands. The Revillagigedo Archipelago occupies the same geographical position relative to Mexico as the Galapagos Islands to Ecuador, each being several hundred kilometers west of mainland America. For this reason, some researchers call the Revillagigedo the Mexican Galapagos [1]. The archipelago consists of four volcanic islands that are located 455 $\mathrm{km}$ south of San Lucas Cape in Baja California Sur and $674 \mathrm{~km}$ west-southwest of Corrientes Cape in Jalisco. The Mexican Navy established a naval base on Socorro Island in 1957, and in 1994 the archipelago was classified by UNESCO as a Natural Protected Area under the denomination of Biosphere Reserve. In 2002 the Mexican government banned commercial fishing in the area [2].

The Revillagigedo Archipelago consists of oceanic islands of volcanic origin that emerge from a volcanic floor along the Clarion Fracture Zone, west of the union of the Pacific, Rivera, and Cocos geologic plates. The Insular Arch of the Revillagigedo Archipelago represents an authentic submarine mountain system, with some summits above sea level, such as the Roca Partida, Socorro, and San Benedicto islands. These islands are surrounded by cliffs, with mountainous areas and interior volcanoes as well as rugged sites, lava fields, and soft crests. The topographic forms are of an endogenous and accumulative nature, but exogenous processes have modified the original volcanic physiognomy, mainly in the central and higher parts, which reach up to $1040 \mathrm{~m}$ above sea level. A submarine volcano is emerging along the northwest coast of Socorro Island [3]. Seismic activity in the region is high; three earthquakes in the Rivera Fracture Zone were recorded in 2010, leading to the expectation of continued activity in nearby fracture zones as well as earthquakes generated by volcanoes on Socorro and San Benedicto Islands [4].

The marine fauna of the archipelago is known for its high diversity of invertebrates, particularly crustaceans [5], mollusks [6]-[8], echinoderms [9], sponges [10], and corals [11] [12], and also for its high level of endemism. Twenty-two species of hermatypic (reef-building) corals inhabit the area; of these, more than a half occur only near oceanic islands of the eastern Pacific and nearly one-third occur only at Revillagigedo Archipelago [13]. In addition, 156 species of mollusks [14], 99 species of echinoderms [9], and 92 species of crustaceans (3 of which are endemic) [5] inhabit the archipelago. The fish fauna also is species rich, with at least 321 species, including 20 species of shark and 5 species of ray [15]-[17]. The waters surrounding the archipelago are an

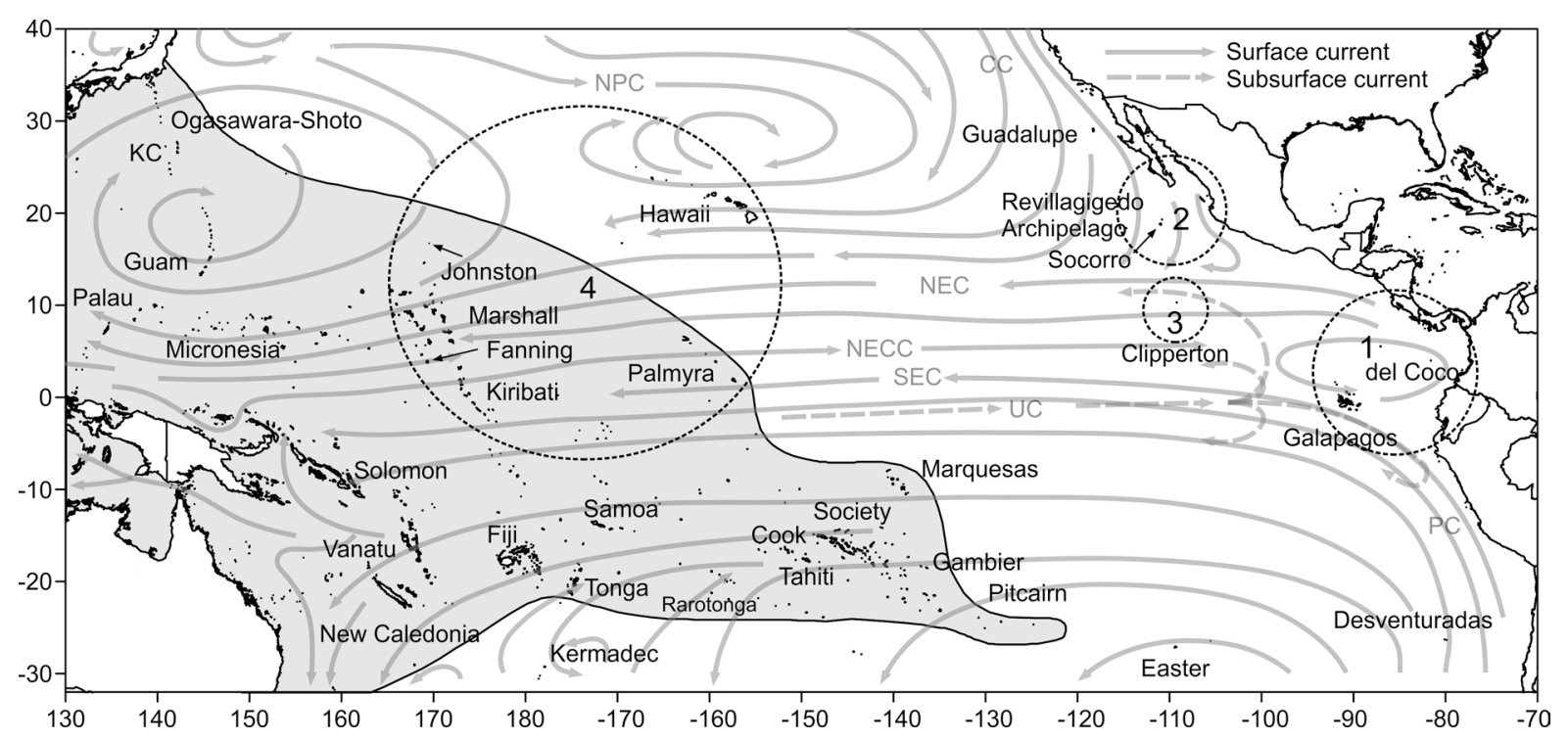

Figure 1. Location of Revillagigedo Archipelago. The heavy line delimits the perimeter of the 50 species contour of reefbuilding corals, and the dashed line shows the four eastern Pacific reef coral provinces: 1) equatorial; 2) northern; 3) Clipperton; and 4) central Pacific. Adapted from [25] [26] [37]-[39]. 
important feeding, breeding, and transit area for cetaceans of the Mexican Pacific, in particular humpback whales [18] [19]. Sixteen species of whales and dolphins have been reported in the area [20]. Four species of sea turtle feed, nest, and grow in the region [21]. Previously, the coral reefs at Socorro were used for paleoclimate studies [22] and El Niño event analysis [23].

Mexican Pacific waters are impacted by a number of natural events. For example, three coral species disappeared from the Revillagigedo Reef after the 1982-1983 ENSO. Recent information about the strong affinity between eastern and central Pacific coral faunas, the abundance of teleplanic larvae in oceanic currents, high genetic similarity of numerous reef-associated species, and the appearance of numerous Indo-western Pacific species in the eastern Pacific following ENSO activity suggest that a mechanism of bridging the East Pacific filter bridge (formerly the East Pacific barrier) could exists.

Despite the critical role of the Revillagigedo Archipelago in the migration of coastal marine species across the eastern Pacific Barrier and the evidence that El Niño-La Niña cause abnormal weather and affect socioeconomic activity all over Mexico, few oceanographic studies in open ocean have been conducted in the region. For this reason, in 2005 the ICML of the UNAM initiated the "Oceanographic Monitoring of Mexican Pacific Ocean Project using Telemetry" mooring an oceanographic buoy near Socorro Island in the Mexican Revillagigedo Archipelago (Figure 2). This paper highlights the information generated during the two years that this buoy was in operation.

\section{Buoy Characteristics and Data Reduction}

The buoy consists of several sensors for monitoring oceanographic and meteorological parameters. Table 1 lists the sensors used. The oceanographic sensors are installed in a S4 Inter Ocean electromagnetic current meter, and the meteorological sensor consists of a Davis weather station. In addition to the buoy sensors, there is a coastal station on Socorro Island equipped with a pressure sensor for recording sea level, tides, and waves. The system was programmed to recognize abnormal variations of sea level (e.g., tsunamis) (Figure 3).
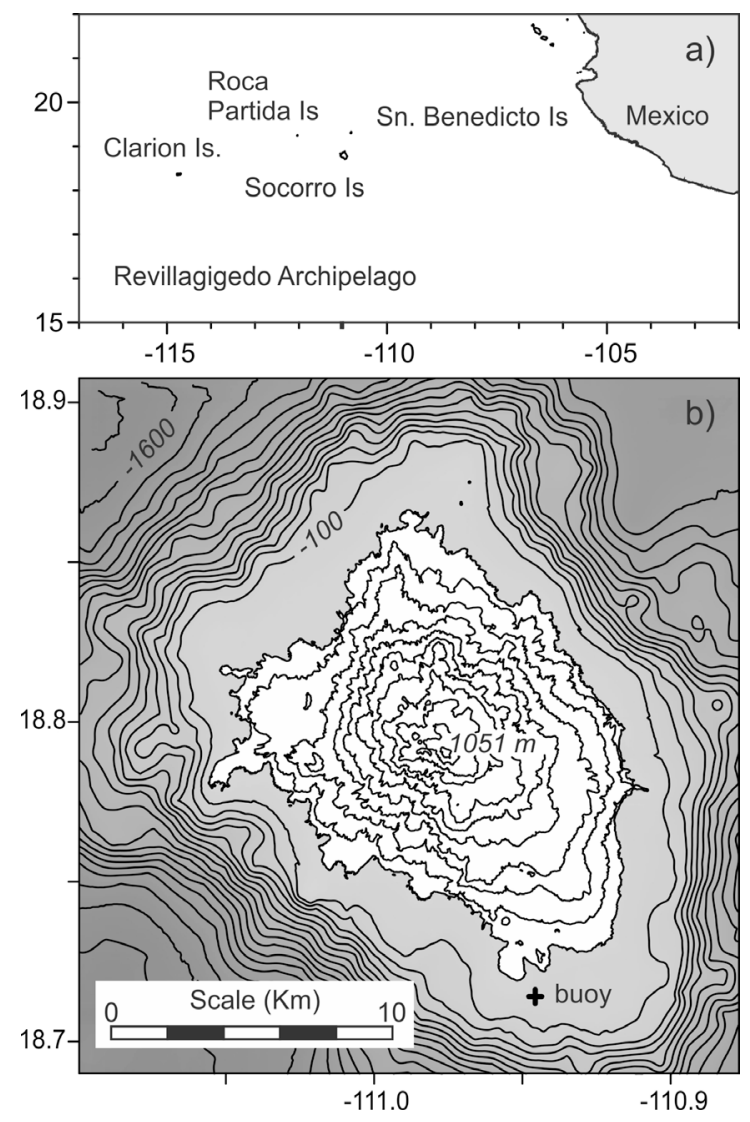

Figure 2. Socorro Island, relief and location of the buoy. 


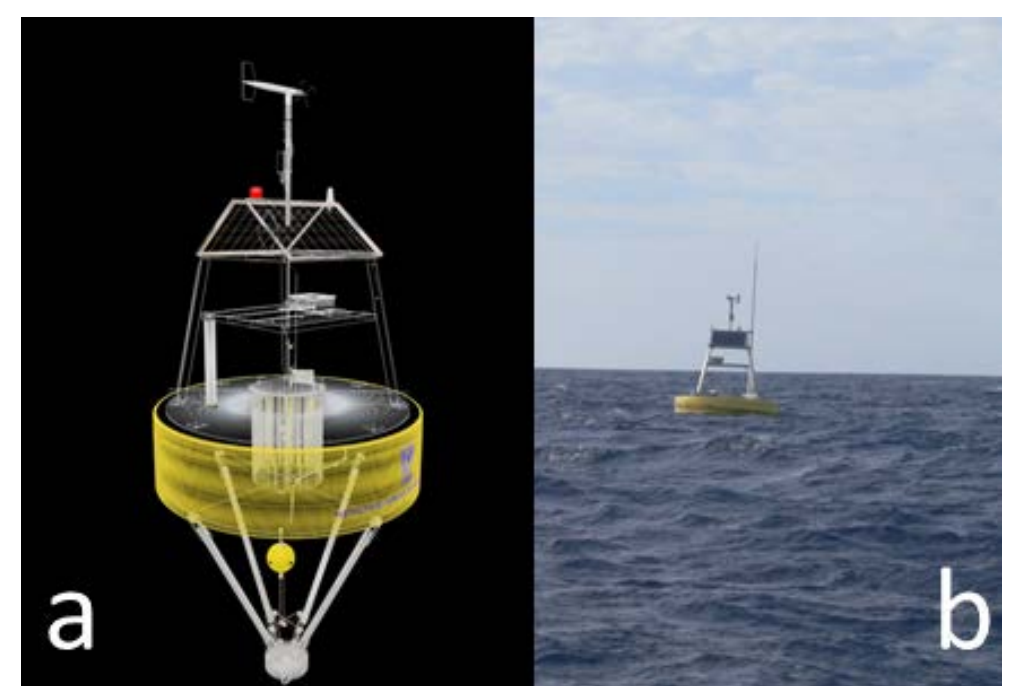

Figure 3. (a) Schematic representation of the buoy; and (b) buoy photograph.

Table 1. Sensor characteristics.

\begin{tabular}{|c|c|c|c|c|c|}
\hline & Minimum & Maximum & Precision & Units & Comments \\
\hline \multicolumn{6}{|l|}{ Meteorological } \\
\hline \multicolumn{6}{|l|}{ Davis Station } \\
\hline Speed & 1 & 80 & $5 \%$ & $\mathrm{~m} \cdot \mathrm{s}^{-1}$ & \\
\hline Direction & 0 & 360 & $5 \%$ & Degrees & \\
\hline Barometer & 540 & 1100 & 0.1 & $\mathrm{hPa}$ & \\
\hline Relative humidity & 0 & 100 & $1 \%$ & $\%$ & \\
\hline Temperature & 0 & 60 & 0.05 & ${ }^{\circ} \mathrm{C}$ & \\
\hline \multicolumn{6}{|l|}{ Oceanographic } \\
\hline \multicolumn{6}{|l|}{ Inter Ocean S4 } \\
\hline Speed & 0 & 750 & $2 \%$ & $\mathrm{~cm} \cdot \mathrm{s}^{-1}$ & \\
\hline Direction & 0 & 360 & 0.5 & Degrees & \\
\hline Memory & & & & & $20 \mathrm{Mb}-7$ billion vectors \\
\hline Clock derive & & & & & \pm 12 minutes by year \\
\hline Tilting & & & & $2 \%$ & 45 degrees with $1 \%$ of correction \\
\hline Conductivity & 1 & 70 & \pm 0.2 & $\mathrm{mS}$ & \\
\hline Temperature & -5 & 45 & \pm 0.02 & ${ }^{\circ} \mathrm{C}$ & \\
\hline $\mathrm{pH}$ & 2 & 12 & 0.001 & & \\
\hline Turbidity & 0 & 200 & 0.01 & FTU & \\
\hline Salinity & & & & & Calculated \\
\hline Density & & & & & Calculated \\
\hline Chlorophyll & 0 & 400 & 0.1 & $\mu g \cdot L^{-1}$ & Calculated \\
\hline \multicolumn{6}{|l|}{ Pressure sensor } \\
\hline Inter Ocean & $\begin{array}{l}\text { Silicon } \\
\text { Crystal }\end{array}$ & & $0.006 \%$ & & $2 \mathrm{~Hz}$ sampling, $\pm 0.15 \mathrm{FS}$ \\
\hline \multicolumn{6}{|l|}{ Data logger } \\
\hline Zeno 3200 & Motorola & 68332 at 32 bits & 8 channels & & $\begin{array}{l}6 \text { modes and } 15 \mathrm{I} / \mathrm{O} \text { directions with } \\
48 \text { options of connections }\end{array}$ \\
\hline
\end{tabular}


The buoy transmitted data hourly from July 11, 2005 to November 15, 2007 and recorded oceanographic data (current speed and direction, conductivity, temperature, salinity, density, turbidity, $\mathrm{pH}$, fluorescence, sea level, waves and tides) and meteorological data(wind speed and direction, temperature, relative humidity, and pressure) in a distant region of the continental part of Mexico (18 $\left.42^{\prime} 50.693^{\prime \prime} \mathrm{N}, 110^{\circ} 56^{\prime} 44.372^{\prime \prime W}\right)$. Additionally it had a computer remote station which allowed us to review via satellite, the buoy conditions and make adjustments. This monitoring station was in the ICML in Mexico City. Data were reduced to eliminate noise, and analyzed via FFT and Morlet wavelets transforms. It must be noted that hurricane effects were filtered from the time series, this information will be used in another publication.

\section{Results and Discussions}

The basic statistics of the recorded data (Table 2) show that the maximum oceanic current component $u$ (1.9 $\left.\mathrm{m} \cdot \mathrm{s}^{-1}\right)$ was twice as large as the maximum velocity component $v\left(0.598 \mathrm{~m} \cdot \mathrm{s}^{-1}\right)$ but that the $v$ negative component was more persistent, meaning that particle displacement was West-South dominant. This current pattern is consistent with data reported by Fiedler [24], Molina-Cruz and Martínez-López [25], Glynn et al. [26], and Pantoja et al. [27]. Water temperature oscillated between $21.53^{\circ} \mathrm{C}$ and $25.74^{\circ} \mathrm{C}$, with a mean of $23.65^{\circ} \mathrm{C}$. Turbidity varied widely, with a maximum value of 158.12 FTU and a minimum value of 37.91 FTU. During the middle of 2005 and the beginning of 2006 the turbidity sensor was not working due to fouling of part of the sensor's surface. This problem could not be solved from the remote station, but it was manually fixed during a maintenance cruise. Afterward, the sensor worked correctly for the remainder of the buoy's deployment. Salinity ranged from 33.59 to 35.37 . $\mathrm{pH}$ had a maximum value of 8.36 and a minimum value of 8.34. The average Chlorophyll $a$ (Chl a) concentration was $4.854 \mu \mathrm{g} \cdot \mathrm{L}^{-1}$, while the maximum was 4.87 and the minimum 4.84 . Both Chla, and $\mathrm{pH}$ data had a very low standard deviation. For other oceanic areas in the Pacific López-Sandoval et al. [28] reported Chl $a$ values higher than $2 \mathrm{mg} \cdot \mathrm{m}^{-3}$ in an area off Cabo Corrientes, and Aguirre-Gomez et al. [29] estimated 0.49 $\mathrm{mg} \cdot \mathrm{m}^{-3}$ in a moreoceanic zone. Off the Costa Rican coast, a mean Chla value of $2 \mu \mathrm{g} \cdot \mathrm{L}^{-1}$ was reported [30], and in the Ecuador-Peru-Chile Ocean region, the average value was $0.141 \mu \mathrm{g} \cdot \mathrm{L}^{-1}$ [31]. Thus, the average Chla concentration measured in this study was comparatively high relative to other oceanic records but lower than values measured along Mexican continental coasts. Socorro Island reef productivity may be affected by this relatively high Chla value.

Sea level ranged from 0 to $2.12 \mathrm{~m}$, with a linear increasing trend that resulted in a $1.4 \mathrm{~mm}$ difference over the two year observation period. The highest level recorded was coincident with a temperature increase. This was

Table 2. Basic statistics.

\begin{tabular}{|c|c|c|c|c|c|}
\hline & Units & Maximum & Minimum & Mean & Std Dev \\
\hline \multicolumn{6}{|l|}{ Oceanographic } \\
\hline$u$ speed & $\mathrm{cm} \cdot \mathrm{s}^{-1}$ & 100.90 & -100.00 & -0.97 & 20.53 \\
\hline$v$ speed & $\mathrm{cm} \cdot \mathrm{s}^{-1}$ & 41.45 & -59.85 & -7.49 & 16.35 \\
\hline Temperature & ${ }^{\circ} \mathrm{C}$ & 25.74 & 21.53 & 23.65 & 0.70 \\
\hline Turbidity & FTU & 158.12 & 37.91 & 108.21 & 30.63 \\
\hline Salinity & & 35.37 & 33.59 & 34.49 & 0.34 \\
\hline Density & $\mathrm{Kg} \cdot \mathrm{m}^{-3}$ & 1025.95 & 1024.35 & 1025.09 & 0.25 \\
\hline $\mathrm{pH}$ & & 8.36 & 8.34 & 8.35 & $<10^{-3}$ \\
\hline Chlorophyll & $\mu g \cdot L^{-1}$ & 4.87 & 4.84 & 4.85 & $<10^{-3}$ \\
\hline Sea level & $\mathrm{M}$ & 2.12 & $<10^{-3}$ & 0.64 & 0.41 \\
\hline Waves & M & 4.97 & 1.03 & 2.74 & 0.69 \\
\hline Waves period & $\mathrm{S}$ & 15.44 & 8.70 & 11.89 & 1.18 \\
\hline \multicolumn{6}{|l|}{ Meteorological } \\
\hline$u$ speed & $\mathrm{m} \cdot \mathrm{s}^{-1}$ & 11.99 & -9.91 & -1.11 & 4.72 \\
\hline$v$ speed & $\mathrm{m} \cdot \mathrm{s}^{-1}$ & 8.88 & -12.32 & -2.79 & 3.55 \\
\hline Temperature & ${ }^{\circ} \mathrm{C}$ & 29.41 & 25.66 & 27.64 & 0.69 \\
\hline Relative humidity & $\%$ & 98.33 & 68.10 & 84.10 & 5.26 \\
\hline Barometer & $\mathrm{hPa}$ & 1114.97 & 1000.74 & 1055.46 & 27.19 \\
\hline
\end{tabular}


related to the intrusion of waters from the southwest or the retraction of the currents coming from the northeast. Maximum wave height was almost $5 \mathrm{~m}$ and the minimum value was $1 \mathrm{~m}$, with an average of $2.742 \mathrm{~m}$. Maximum and minimum wave periods were $15.44 \mathrm{~s}$ and $8.70 \mathrm{~s}$, respectively, with an average of $11.893 \mathrm{~s}$. Wave height and period showed a behavior similar to that of sea level, temperature, salinity, and currents. This suggests that waves may be influenced by current oscillations or eddies [32] that cross the Revillagigedo Islands.

On January 6, 2006, a 7.6 magnitude earthquake in the Banda Sea generated atsunami. The buoy recorded this has a small teletsunami approximately $8 \mathrm{~h}$ later, as a sea level variation of $25 \mathrm{~cm}$ (Figure 4).

Ocean currents generally showed similar behavior as wind. In the open ocean, surface currents are strongly correlated to wind stress forcing. In coastal regions, friction plays an important role in reducing the magnitude of the ocean currents and the relationship between the currents and the wind is not so linear. The fact that ocean currents and winds were highly correlated in Socorro Buoy shows that there is not a significant island effect, which means that the data are representative of open ocean data. Like ocean currents and winds, air temperature and ocean temperature exhibited a similar relationship. The maximum wind speed was $12.32 \mathrm{~m} \cdot \mathrm{s}^{-1}$, relative humidity varied between $84.10 \%$ and $98.33 \%$, and barometric pressure varied between 1100 and $1000.74 \mathrm{hPa}$. It must be noted that hurricane effects were filtered from the time series.

Analysis of the current time-series data (Figures 5-7) and the spectral density (Figure 8) revealeda three month periodic illation among the astronomical principal tidal lunar and solar peaks. The linear spectral analysis (Figure 8) and the wavelet analysis (Figure 9) showed annual, seasonal, and biweekly frequencies, frequencies associated with the main tidal components, and frequencies corresponding to inertial oscillations. The spectral components of the $u$ and $v$ ocean current components showed peaks at 12.42 and $24 \mathrm{~h}$, corresponding to the principal lunar $\left(M_{2}\right)$ and solar $\left(K_{1}\right)$ tidal components, respectively. At this location, the theoretical inertial oscillation ( $f$ in Figure 8) indicated a period of $37.40 \mathrm{~h}$, the Chla, $\mathrm{pH}$, temperature, turbidity, and $u$ component of velocity all showed well-defined peaks at this period, whereas they were not so evident in the $v$ component. Nevertheless, three more peaks at low frequencies that contributed significantly to the spectral energy of the time series were detected. Salinity, $u$, and $v$ component spectra also showed these three peaks, but in a semisquare band configuration that can be attributed to spectral aliasing. The oceanic spectral peaks occurred mainly between frequencies of $10^{-1}$ to $10^{-3} \mathrm{cph}$, representing diurnal to monthly periods. This spectral band represented more than $80 \%$ of the total variance. Figure 6 shows a close up view of a 6 month time series of Chla, turbidity, and $\mathrm{pH}$ in which the spring tidal effects are evident. The meteorological time-seriesspectrum (Figure 8) shows peaks at the same frequencies as the oceanographic time series.

We also applied MorletTrans form (MWT) to obtain wavelets and to analyze signals with high frequency harmonic components during very short periods and low frequency harmonics during long periods. Fourier

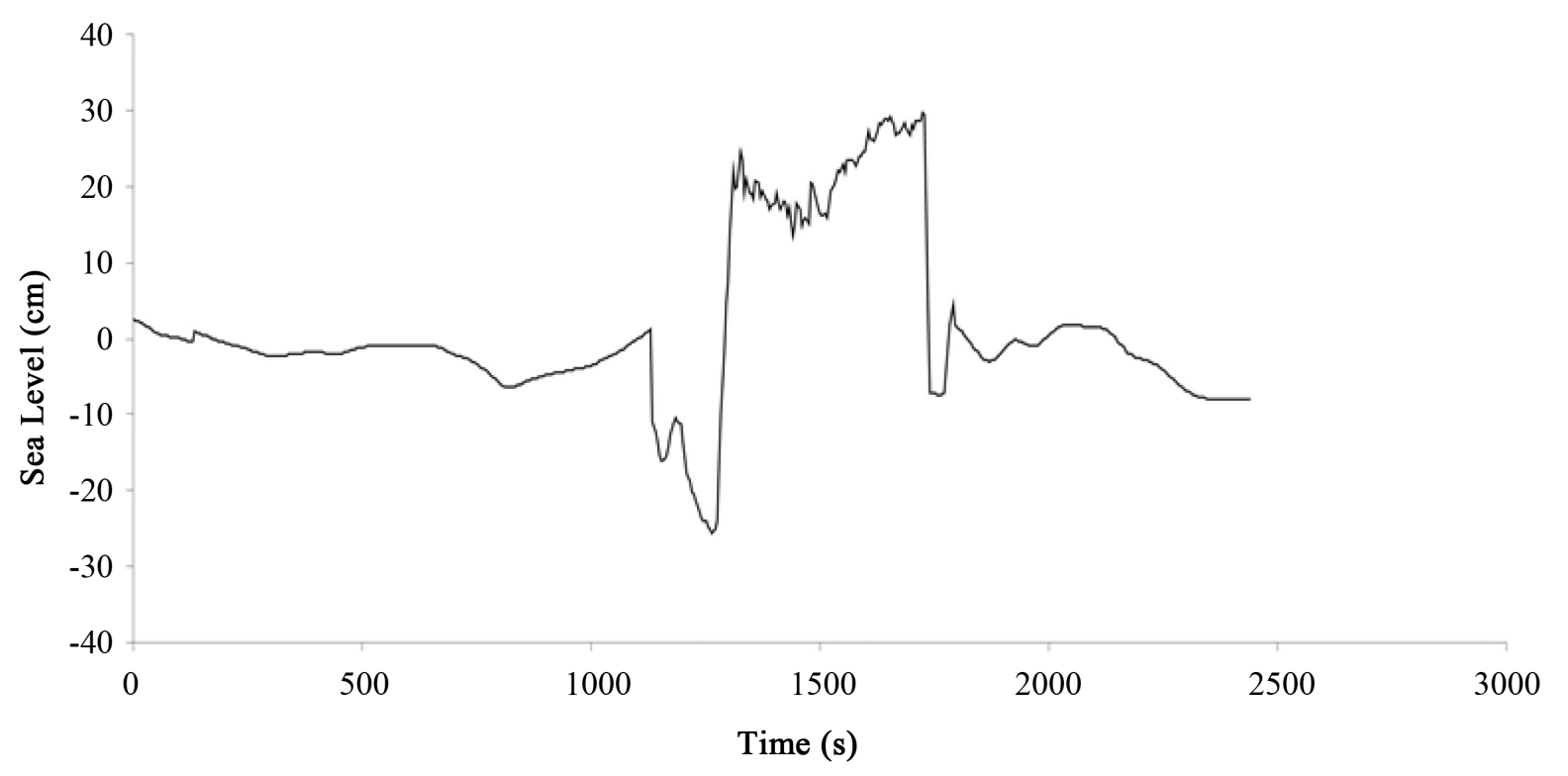

Figure 4. Sea level and teletsunami of the January 6, 2006 at Banda Sea along the Socorro Island coast. 

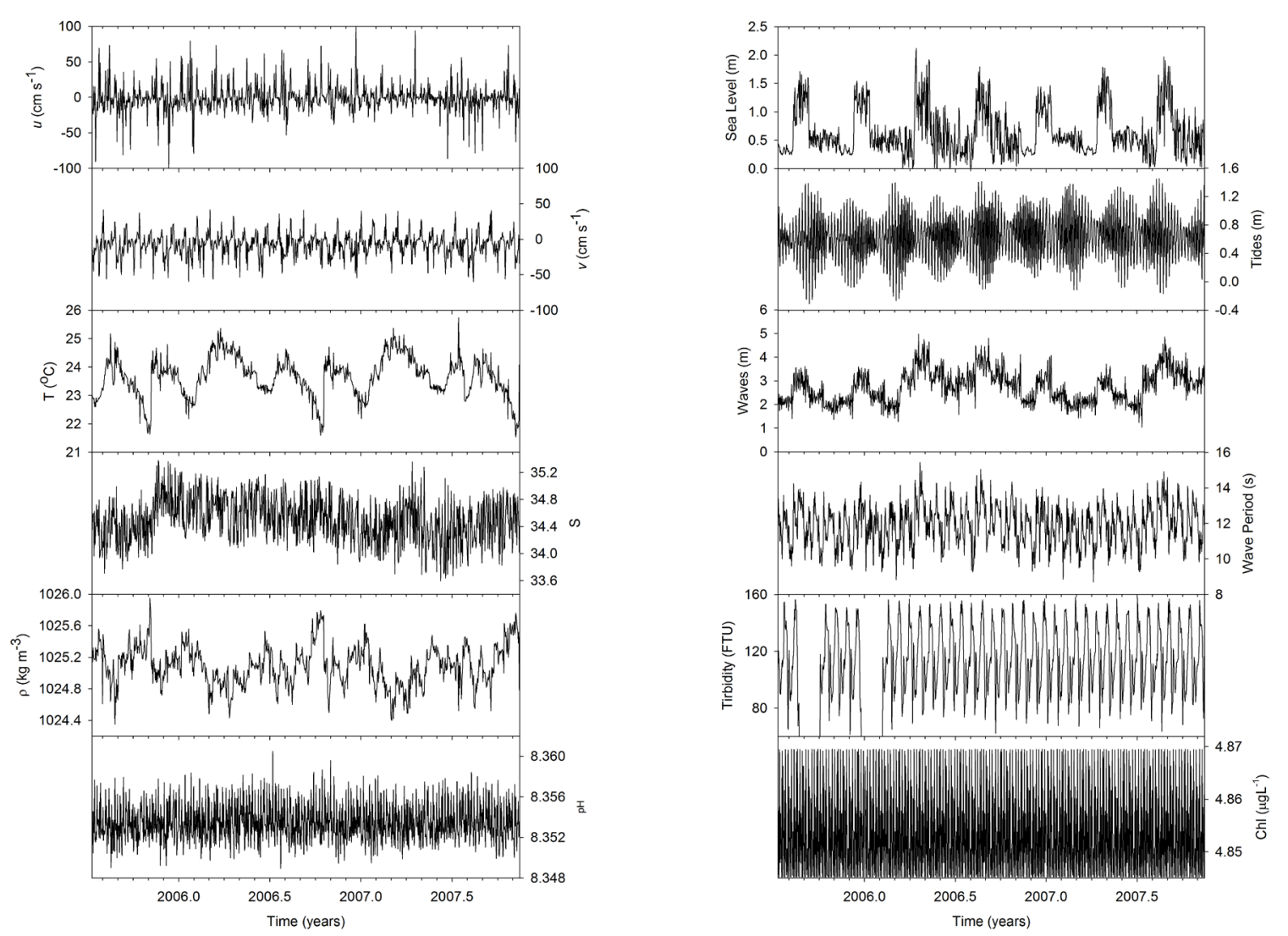

Figure 5. Time series of oceanographic data.

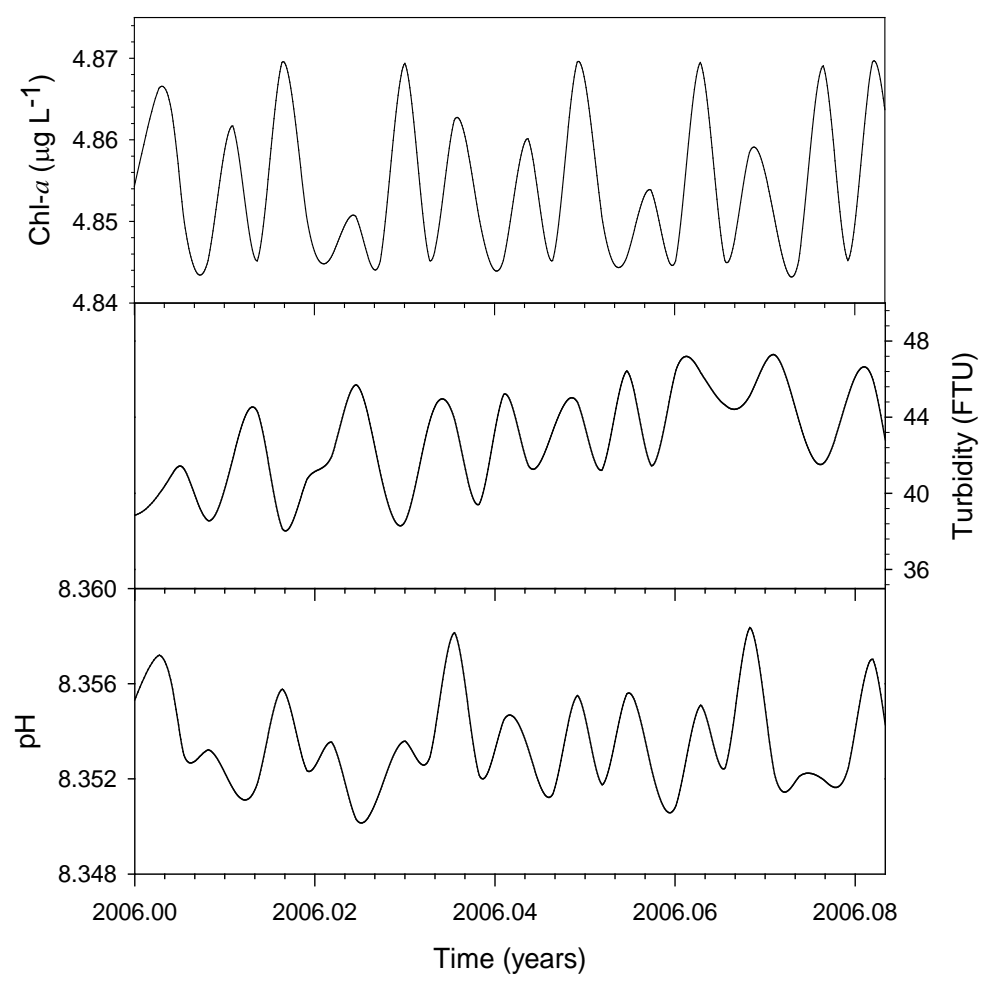

Figure 6. Close up view of Chla, turbidity, and pH time-series data. 


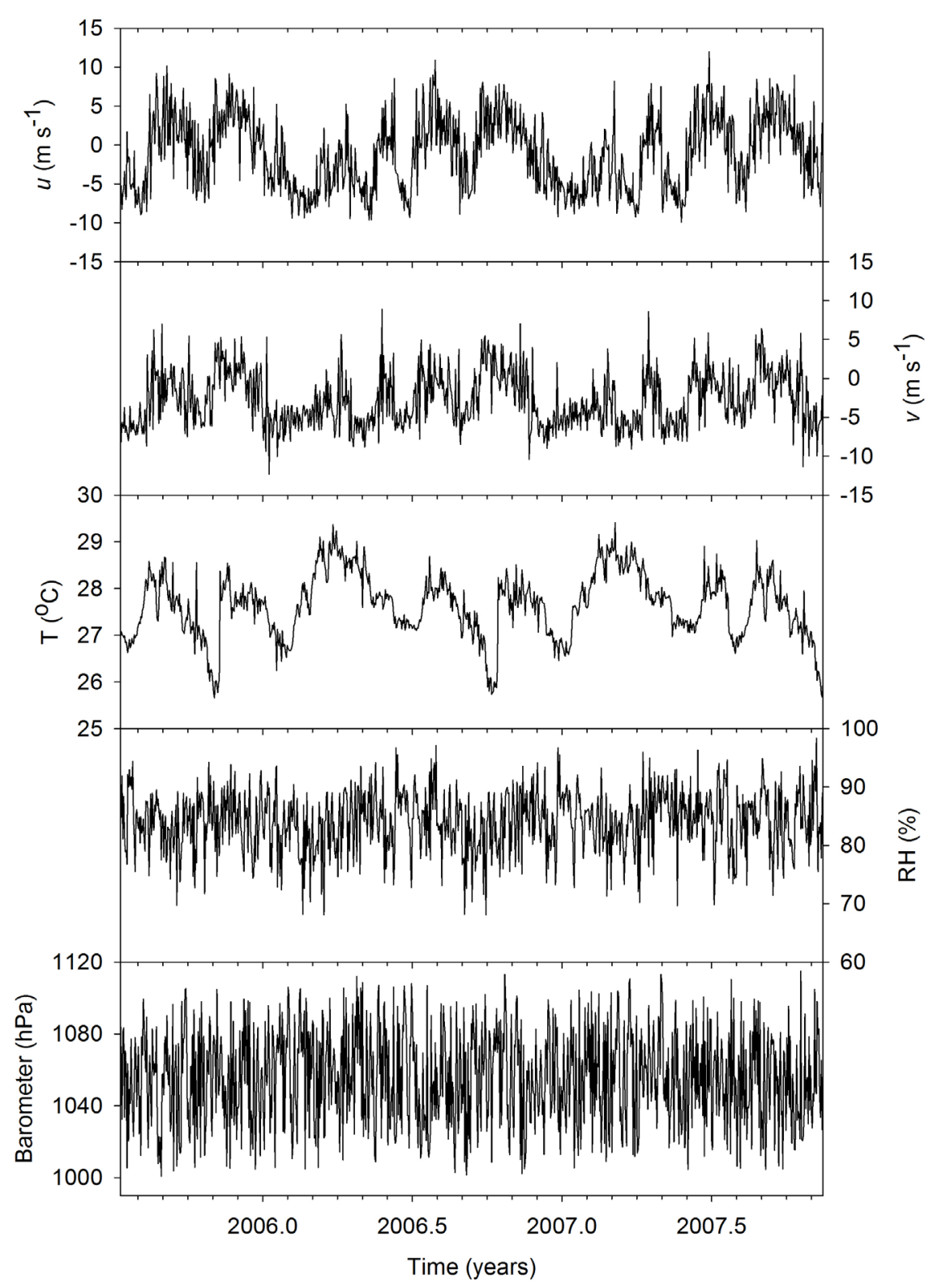

Figure 7. Time series of meteorological data.

transform is a powerful technique useful for analyzing the frequency component over whole time, but it cannot match the changes in frequency response with respect to time. In the wavelets of the oceanic and atmospheric series (Figure 9), separation of the different frequencies is clearly visible. The Morlet wavelet established a clear distinction between the random fluctuations and the periodic patches. A shift in frequencies occurred at 200, 400, 500, and $700-800$ days in the $u$ currents, whereas the $v$ component followed a more stable path. Temperature, density, wave high, and sea level showed a perturbation at 100 days. Salinity, wave period, and the $v$ current component did not exhibit clear time perturbations. Except for air temperature, the atmospheric time series exhibited lower time variations in periodicities. The $u$ and $v$ air velocity components had time lags at 200 and 550 days, where as temperature was noisier, with variation periods every 200 - 300 days.

Finally, the wavelet map revealed a gradual shift of local maxima and minima toward shorter durations. An oscillation centered at 30 - 40 days is clearly visible in all of the wavelet representations, and these wave packets had periods similar to those of the Madden-Julian Oscillation [33]-[35]. This oscillation has been associated with extreme precipitation events in western North America. Yimin and Stocker [36] reported that fire, wind, and 


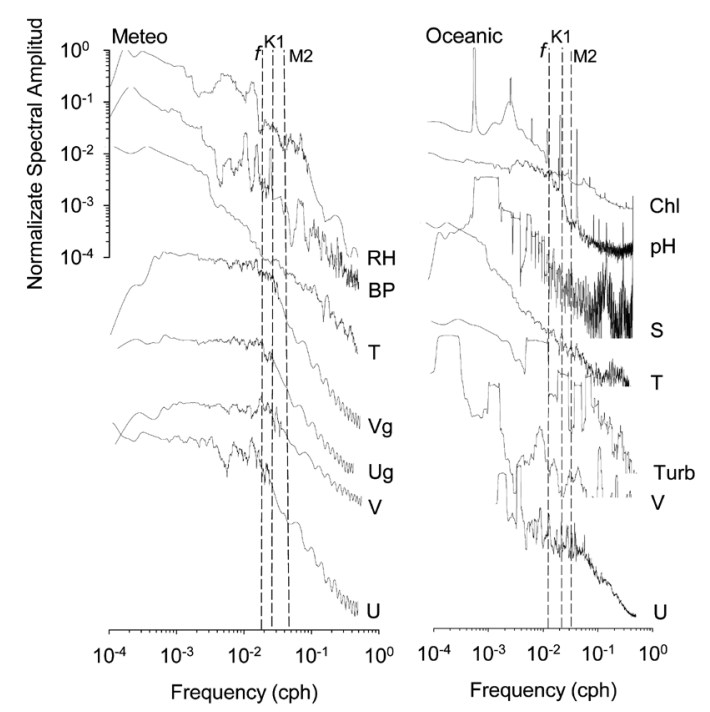

Figure 8. Power spectrum for oceanic and meteorological buoy data. The spectrum was generated with 14 degrees of freedom obtained by smoothing.
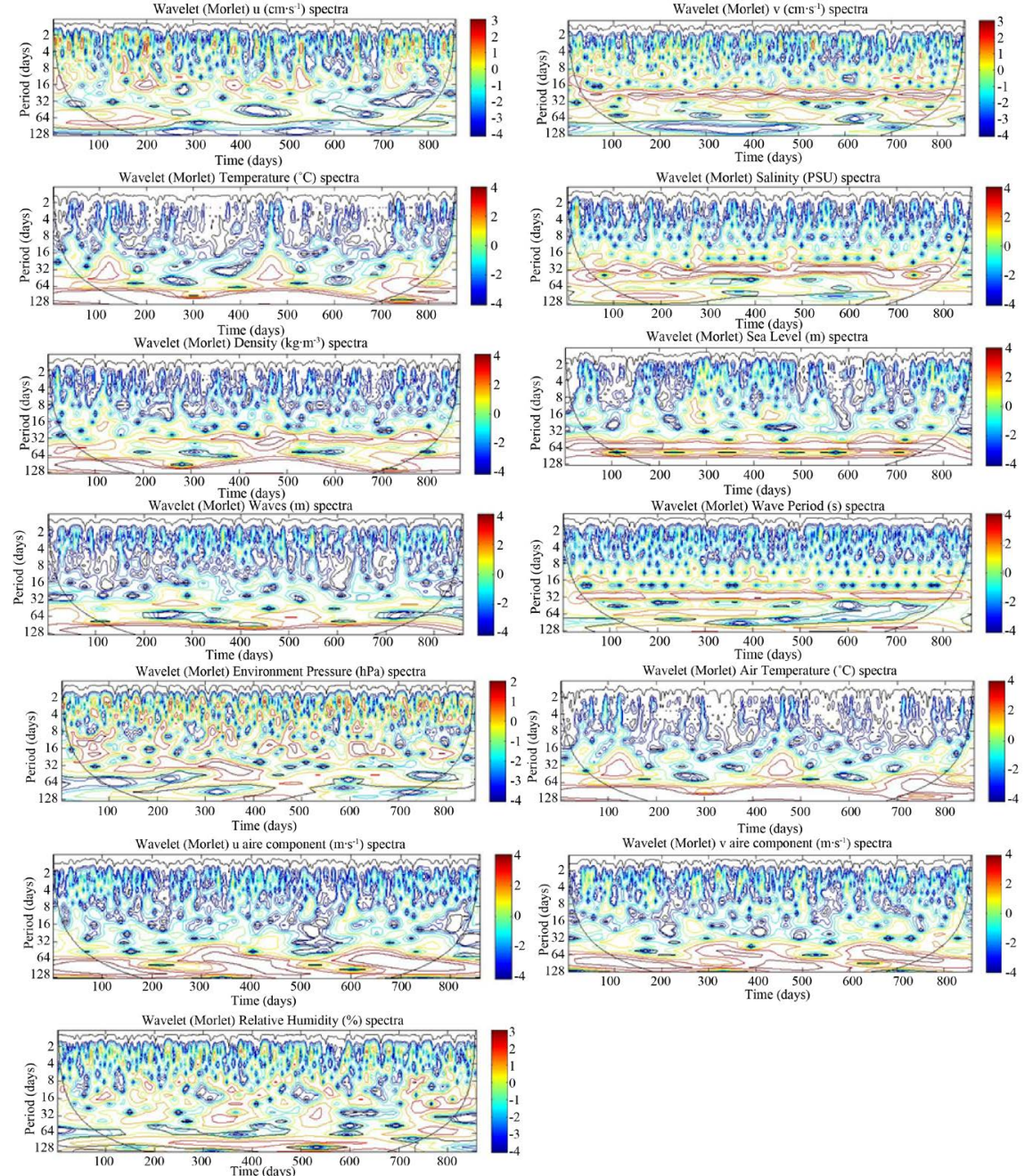

Figure 9. Wavelets (Morlet) spectrum. 
precipitation data showed a pattern similar to that of the Madden-Julian 30 - 60 day oscillation mode of meteorological parameters in the tropics.

\section{Conclusion}

The linear spectral analysis and wavelet analysis revealed annual, seasonal, and biweekly frequencies, frequencies associated with the main tidal components, and frequencies corresponding to inertial oscillations. Statistical analysis showed a southwest dominant current and variations induced by the passing of different types of mesoscale eddy in this region, as well as the possibility of Madden-Julian Oscillations.

\section{Acknowledgements}

We thank the officers and crew of R/V El Puma of the Universidad Nacional Autónoma de México. It would not have been possible to conduct this work without the support of the Mexican Navy, and we thank all officers and personnel who helped us during the time that the buoy was anchored on Socorro Island.

\section{References}

[1] De la Torre, J.A., López-Damián, L.J., Bárcenas, H.V., Nájera-Solís, E. and Medellín, R.A. (2010) New Record of sheep Frog (Hypopachus variolosus) in the Tres Marías Islands Archipelago, Nayarit, Mexico. Revista Mexicana deBiodiversidad, 81, 581-582.

[2] Ortega-Rubio A. and Castellanos-Vera, A. (1994) La Isla Socorro, Reserva de la Biosfera Archipielago de Revillagigedo, México. Centro de Investigaciones Biológicas del Noroeste S.C., Publication Number 8, La Paz, B.C.S.

[3] Bondarenko, V.I. and Rashidov, V. (1996) A Survey of a Submarine Volcanic Ridge North of San Benedicto Island. Volcanology and Seismology, 17, 699-704.

[4] Valenzuela, R.W., Pacheco, J.F., Pereita, J., Estrada, J.A., Pérez, J.A., Cruz, J.L., Baturan, D., Cárdenas, A. and Santiago, J.A. (2007) The Seismic and Hydroac Oustic Station on Socorro Island: Early Results. Geofísica Internacional, 46, 3-18.

[5] Hernández-Aguilera, J.L. (2002) Crustaceans of the Revillagigedo Archipelago (Stomatopoda and Decapoda from Thalassinidea to Brachyura), Eastern Tropical Pacific. Contribuciones al Estudio de los Crustáceosdel Pacifico Este, Instituto de Ciencias del Mar y Limnología, Universidad Nacional Autónoma de México Publisher, México.

[6] Holguín-Quiñones, O.F. and Michel-Morfín, J.E. (2002) Distribution, Density and Length-Weight Relationship of Chiton articulates Sowerby, 1832 (Mollusca-Polyplacophora) on Isla Socorro, Revillagigedo Archipelago, Mexico. Journal of Shellfish Research, 21, 239-241.

[7] Mille-Pagaza, S., Carrillo-Laguna, J., Pérez-Chi, A. and Sánchez-Salazar, M.E. (2002) Abundancia y diversidad de los invertebrados Litorales de Isla Socorro, Archipiélago Revillagigedo, México. Revista de Biología Tropical, 50, 97-105.

[8] Behrens, D., Gosliner, T. and Hermosillo, A. (2009) A New Species of Dorid Nudibranch (Mollusca) from the Revillagigedo Islands of the Mexican Pacific. Proceedings of the California Academy of Sciences, 60, 423-429.

[9] Caso, M. (1976) Present State of the Study of Mexican Echinoderms. Analesdel Centro de Ciencias del Mar y Limnolgía de la Universidad Nacional Autónoma de México, 42, 1-56.

[10] Cruz-Barraza, J., Carballo, J., Bautista-Guerrero, E. and Nava, H. (2011) New Species of Excavating Sponges (Porifera: Demospongiae) on Coral Reefs from the Mexican Pacific Ocean. Journal of the Marine Biological Association of the United Kingdom, 91, 999-1013. http://dx.doi.org/10.1017/S0025315410002079

[11] Reyes-Bonilla, H., Pérez-Vivar, T.L. and Ketchum-Mejía, J.T. (1999) Distribucióngeográfica y depredación de Poriteslobata (Anthozoa: Scleractinia) en la costa occidental de México. Revista de Biología Tropical, 47, 273-279.

[12] Ketchum, J. and Reyes Bonilla, H. (2001) Taxonomy and Distribution of the Hermatypic Corals (Scleractinia) from the Revillagigedo Archipelago, Mexico. Revista de Biología Tropical, 49, 803-848.

[13] Carricart-Ganivetand, J. and Reyes-Bonilla, H. (1999) New and Previous Records of Scleractinian Corals from Clipperton Atoll, Eastern Pacific. Pacific Science, 53, 370-375.

[14] Bonilla, H. (1999) Additions to the 1995 Summary of Marine Mollusks of the Islas Revillagigedo (Tropical Eastern Pacific Ocean, Mexico). Festivus, 31, 31-40.

[15] Gotshall, D.W. (2015) Marine Animals of Baja California: A Guide to Thecommonfishes and Invertebrates SEA CHALLENGERS, MONTEREY, CA (USA). http://search.proquest.com/docview/14886874?accountid=14598

[16] Robertson, D.R. and Allen, G.R. (1996) Zoogeography of the Shorefish Fauna of Clipperton Atoll. Coral Reefs, 15, 121-131. http://dx.doi.org/10.1007/BF01771902 
[17] Aburto-Oropeza, O. and Hull, P.M. (2008) A Probable Spawning Aggregation of the Leather Bass Dermatolepis dermatolepis (Boulenger) in the Revillagigedo Archipelago, México. Journal of Fish Biology, 73, 288-295. http://dx.doi.org/10.1111/j.1095-8649.2008.01909.x

[18] Lagerquist, B., Mate, B., Ortega-Ortiz, J., Winsor, M. and Urban-Ramirez, J. (2008) Migratory Movements and Surfacing Rates of Humpback Whales (Megaptera novaeangliae) Satellite Tagged at Socorro Island, Mexico. Marine Mammal Science, 24, 815-830.

[19] Calambokidis, J., Steiger, G., Rasmussen, K., Urban, R., Balcomb, K., Guevara, P., Salinas, Z., Jacobsen, J., Baker, C., Herman, L., Cerchioand, S. and Darling, J. (2000) Migratory Destinations of Humpback Whales That Feed off California, Oregon and Washington. Marine Ecology Progress Series, 192, 295-304. http://dx.doi.org/10.3354/meps192295

[20] Mate, B. and Urban, J. (2007) Spring Migration and Summer Feeding Destinations of Humpback Whales Wintering at Socorro Island, Mexico. Eos Transactions American Geophysical Union, 05-01.

[21] Holroyd, G. and Trefry, H. (2010) The Importance of Isla Clarion, Archipelago Revillagigedo, Mexico, for Green Turtle (Cheloniamydas) Nesting. Chelonian Conservation and Biology, 9, 305-309. http://dx.doi.org/10.2744/CCB-0831.1

[22] Villaescusa, J.A. and Carriquiry, J.D. (2004) Calibration of Sr/Ca and Mg/Ca Paleothermometers in Coral Porites sp. from San Benedicto Island, Revillagigedo Archipelago, Mexico. Ciencias Marinas, 30, 603-618.

[23] Linsley, B., Ren, L., Dunbar, R. and Howe, S. (2000) El Nino Southern Oscillation (ENSO) and Decadal-Scale Climate Variability at 10 Degree N in the Eastern Pacific from 1893 to 1994: A Coral-Based Reconstruction from Clipperton Atoll. Paleoceanography, 15, 322-335. http://dx.doi.org/10.1029/1999PA000428

[24] Fiedler, P. (1992) Seasonal Climatologies and Variability of Eastern Tropical Pacific Surface Waters. NOAA Technical Report NMFS, US Department of Commerce, 70 .

[25] Molina-Cruz, A. and Martinez-López, M. (1994) Oceanography of the Gulf of Tehuantepec, Mexico, Indicated by Radiolaria Remains. Palaeogeography, Palaeoclimatology, Palaeoecology, 110, 179-195. http://dx.doi.org/10.1016/0031-0182(94)90083-3

[26] Glynn, P.W., Veron, J.E.N. and Wellington, G.M. (1996) Clipperton Atoll (Eastern Pacific): Oceanography, Geomorphology, Reef-Building Coral Ecology and Biogeography. Coral Reef, 15, 71-99. http://dx.doi.org/10.1007/BF01771897

[27] Pantoja, D.A., Marinone, S.G., Parés-Sierra, A. and Gómez-Valdivia, F. (2012) Numerical Modeling of Seasonal and Mesoscale Hydrography and Circulation in the Mexican Central Pacific. Ciencias Marinas, 38, 363-379. http://dx.doi.org/10.7773/cm.v38i2.2007

[28] López-Sandoval, D.C., Lara-Lara, J.R., Lavín, M.F., Álvarez-Borrego, S. and Gaxiola-Castro, G. (2009) Primary Productivity in the Eastern Tropical Pacific off Cabo Corrientes, Mexico. Ciencias Marinas, 35, 169-182.

[29] Aguirre-Gómez, R., Salmerónand, O. and Álvarez, R. (2003) Effects of ENSO off the Southwest of Mexico, 19961999. Geofísica Internacional, 42, 377-388.

[30] Huot, Y., Brown, C.A. and Cullen, J.J. (2005) New Algorithms for MODIS Sun-Induced Chlorophyll Fluorescence and a Comparison with Present Data Products. Limnology and Oceanography: Methods, 3, 108-130.

[31] Correa-Ramirez, M.A., Hormazabal, S.E. and Morales, C.E. (2012) Spatial Patterns of Annual and Interannual Surface Chlorophyll-A Variability in the Peru-Chile Current System. Progress in Oceanography, 92, 8-17. http://dx.doi.org/10.1016/j.pocean.2011.07.008

[32] Peregrine, D.H. (1976) Interaction of Waterwaves and Currents. Advanced in Applied Mechanics, 16, 9-117.

[33] Madden, R.A. and Julian, P. (1971) Detection of a 40-50 Day Oscillation in the Zonal Wind. Journal of the Atmospheric Sciences, 28, 1109-1123. http://dx.doi.org/10.1175/1520-0469(1971)028<0702:DOADOI>2.0.CO;2

[34] Madden, R.A. (1986) Seasonal Variations of the 40-50 Day Oscillation in the Tropics. Journal of the Atmospheric Sciences, 43, 3138-3158. http://dx.doi.org/10.1175/1520-0469(1986)043<3138:SVOTDO >2.0.CO;2

[35] Hendon, H.H. and Salby, M.L. (1994) The Life Cycle of the Madden-Julian Oscillation. Journal of the Atmospheric Sciences, 51, 2225-2237. http://dx.doi.org/10.1175/1520-0469(1994)051<2225:TLCOTM>2.0.CO;2

[36] Yiminand, J. and Stocker, E. (2002) Seasonal, Intraseasonal, and Interannual Variability of Global Land Fires and Their Effects on Atmospheric Aerosol Distribution. Journal of Geophysical Research: Atmospheres, 107, ACH 10-1ACH 10-11. http://dx.doi.org/10.1029/2002JD002331

[37] Stoddart, D.R. (1992) Biogeography of the Tropical Pacific. Pacific Science, 46, 276-293.

[38] Veron, J.E.N. (1995) Coral in Space and Time: The Biogeography and Evolution of the Scleractinia. Cornell University Press, Ithaca, NY, $321 \mathrm{p}$.

[39] Gorshkov, S.G. (1976) World Ocean Atlas Vol. 1 Pacific Ocean (English Version). Pergamon Press, Oxford, 333 p. 